\title{
Chapter 20 \\ Challenging a Hybrid Between Green and Gray Infrastructure: Coastal Sand-Covered Embankments
}

\author{
Hajime Matsushima and Xiangmei Zhong
}

\begin{abstract}
While coastal areas are one of the most highly developed areas in the world, they have always been exposed to the danger of disaster. In response to the extreme events that increase every year owing to the effects of climate change, it is necessary to switch from coastal conservation that relies on existing infrastructure (gray infrastructure) to green infrastructure that utilizes ecotone. However, the reproduction of ecotones poses great challenges in many coastal areas. Therefore, we introduce a new approach to the complementary infrastructure development of gray and green functions, which involves conversion of the existing infrastructure, namely tide embankment, into dunes with sand-covering their slope, to be utilized as hybrid infrastructure. It was confirmed that the sand-covered embankments expanded the habitat of dune plants and protected the tide embankment body from high temperatures. This sand-covered embankment was also used as a place for environmental education for local elementary and junior high school students, and the multi-functionality of the hybrid infrastructure that grows over time was confirmed through the participation of various individuals.
\end{abstract}

Keywords Coast · Ecotone $\cdot$ Hybrid infrastructure $\cdot$ Eco-DRR $\cdot$ Sand-covered embankment $\cdot$ Environmental education · Disaster prevention education

\subsection{Introduction}

Millions of people rely on the proximity to the coast for their livelihoods because of their provision of opportunities for trade, economic activities, recreation, and livelihoods (Brown et al. 2014). It has been estimated that the percentage of the

\footnotetext{
H. Matsushima $(\bowtie)$

Research Faculty of Agriculture, Hokkaido University, Sapporo, Japan

e-mail: matts@res.agr.hokudai.ac.jp

X. Zhong

Graduate School of Agriculture, Hokkaido University, Sapporo, Japan
}

(C) The Author(s) 2022

F. Nakamura (ed.), Green Infrastructure and Climate Change Adaptation, Ecological Research Monographs, https://doi.org/10.1007/978-981-16-6791-6_20 
world's population living in a near-coastal zone (below an elevation of $100 \mathrm{~m}$, and closer than $100 \mathrm{~km}$ from the coast) was $28 \%$ (1.9 billion) in 2010 (Kummu et al. 2016).

Along with the population increase and rapid economic growth in coastal areas, there has been extensive conversion to urban and industrial zones, especially in the metropolitan inner bay areas, such as Tokyo Bay in Japan, where natural coastal lines that are mainly composed of tidal flats have disappeared due to development. Dense development along coastal areas has resulted in the loss of beaches and tidal flats as buffer zones between the sea and land, otherwise known as coastal ecotones. Furthermore, such developments are responsible for the deterioration of the inner bay environment, along with the loss of the water purification function of tidal flats as well as the functions of buffer zones to reduce the impact of natural disturbances such as strong wind, salt spray, and sand transportation.

This has resulted in a higher disaster risk due to the increased exposure of coastal communities to natural hazards, especially considering that storm surge disasters caused by extreme weather conditions and a rise in sea level are increasing every year. The IPCC estimated the global mean sea level (GMSL) rise in the Fifth Assessment Report (AR5). Under the most pessimistic scenario (RPC8.5), GMSL was likely to rise $0.45-0.82 \mathrm{~m}$ by $2081-2100$. The impact of this GMSL rise seems small; however, it would lead to a loss of $83 \%$ of the Japanese coastal beach areas (Udo and Takeda 2017).

These predictions show that the developed coastal areas along the beach are exposed to high risks of disasters. To reduce disaster risks and exposure to natural hazards in developed coastal areas, it is necessary to construct larger and stronger structures, such as seawalls or tide embankments. These concrete structures have protected the coastal areas of Japan and supported their economic development throughout the latter half of the twentieth century.

The Ministry of Land, Infrastructure, Transport and Tourism in Japan reported that Japanese social capital stock management (allotted to build new infrastructure and/or maintain the existing ones) would not be sustainable beyond the year 2037 . This alert was made based on a predictive budget shortage that resulted from increasing maintenance costs of concrete infrastructures as well as an aging and declining population. In particular, for shrinking cities (a designation for the urban areas becoming unpopulated due to population decline, a concerning phenomenon otherwise occurring in Japan), it is not feasible to construct larger and stronger concrete structures to deal with the situation. In other words, there is no choice besides using green infrastructure concepts to adapt to recent extreme weather events caused by climate change.

The concrete structures, otherwise known as "gray infrastructures" (for example, seawalls), have a single specific function (for example, coastal protection) and generally have superior effects as compared to natural ecosystems known as "green infrastructure (GI)" (for example, coastal sand dunes). However, many studies and reports have highlighted that multifunctional GI is often better than gray infrastructure in terms of overall capacity. GI helps protect and restore naturally functioning ecosystems and provides economic benefits such as facilitating an 
increase in property values and a decrease in the costs of public infrastructure and services. Investing in GI is often more cost effective than developing conventional public work projects such as flood control, water treatment systems, and storm water management (Benedict and McMahon 2002). However, the high degree of uncertainty in GI functions has been regarded as a problem when compared to those known for gray infrastructure (Onuma and Tsuge 2018). Since such discussions in the past were often unproductive and polarized between the gray and green approaches, it becomes necessary to consider a hybrid infrastructure that complementarily integrates both concepts (Nakamura et al. 2019).

This chapter outlines the functions of coastal ecotones as GI. We propose a hybrid infrastructure that functions complementarily to gray infrastructure, using seawalls on the Sendai coast, which was severely damaged by the tsunami disaster caused by the Great East Japan Earthquake on March 11, 2011, for instance.

\subsection{Coastal Ecotones}

Coastal landscapes, especially natural sandy coasts, are dynamic and ever-changing ecosystems in the vicinity of others such as shallow water bodies (coastal lagoons, estuaries, mangroves, fjords, etc.), sandy beaches, grasslands (dunes), shrubs, saltmarshes, forests, etc. (Fig. 20.1; Wootton et al. 2016). Such areas in which different biological communities, ecosystems, and biotic regions are in contact with each other are called ecotones. They are often steep transitional areas resulting

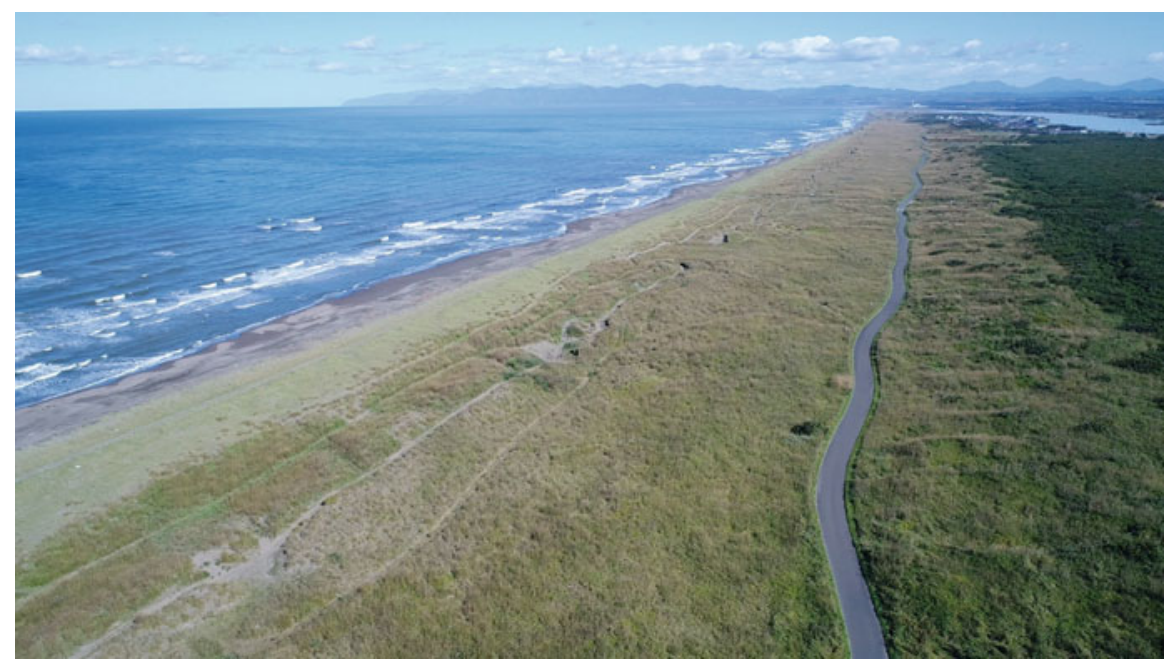

Fig. 20.1 Coastal ecotone of Ishikari coast, Hokkaido, Japan. Easily identifiable transition of ecosystem units by the distance from shoreline (differences in natural disturbance intensity) 
from spatial gradients of abiotic and biotic environmental parameters (Kark 2013). In an ecotone, each ecosystem is maintained through a mutual relationship with the adjacent ecosystem. Therefore, it is important not only to protect individual ecosystems but also to maintain connectivity with the surrounding environment (Kark 2013).

Coastal ecotones have provided diverse ecosystem services. Liquete et al. (2013) defined the following services: provisioning services (fisheries, wood for buildings, and fuels), regulating and maintenance services (habitat for both fauna and flora, nutrient cycling, erosion prevention, waste-water treatment, moderation of extreme events), and cultural services (tourism, recreational, esthetic, and spiritual benefits), as listed in Table 20.1. These services also support the high resilience of coastal ecotones. Because sandy beaches are unstable landscapes, they are eroded by wind and waves, with the dunes covered with dune plants. These plants can cope with high sediment mobility by collecting airborne sand grains with their leaves and stems, protecting the sand from being blown away by the wind using their grass blades, and stabilizing the sand by fast-growing extensive and branched roots and rhizomes (Wootton et al. 2016). In addition, they can rapidly grow upward, surpassing sand burial and toward the sea, expanding the dune to zones of bare sand (Wootton et al. 2016). Therefore, these dune plants are responsible for dune formation and restoration after extreme weather events, coastal erosion, and human intervention (for example, off-road vehicles driven on coastal dunes) through autonomous resilience (Fig. 20.2). However, in order for dune plants to exert this autonomous resilience, it is necessary to not only protect the coastal ecotone itself but also manage the watershed sediment system in an integrated manner. In other words, it is important to maintain connectivity and sustainable dynamic stability, in which the ecosystem units that constitute the ecotone can function complementarily.

\subsection{Recovery and Reconstruction from the Disaster of the Great East Japan Earthquake Using Gray Infrastructures}

A catastrophic earthquake with Mw 9.0 occurred on March 11, 2011, at a depth of approximately $25 \mathrm{~km}$ and $130 \mathrm{~km}$ offshore of the northeastern part of Japan, and it was later named the Great East Japan Earthquake. This event had the largest magnitude ever recorded in Japan and continues to be the fourth-largest in the world since 1900. The earthquake also brought about a tsunami disaster, with an inundation area of approximately $500 \mathrm{~km}^{2}$, registering $18,428 \mathrm{dead}$ and missing people and 404,893 destroyed buildings (NPA 2020). Following the tsunami disaster in the coastal areas of eastern Japan, especially on the Pacific side of the Tohoku region, the Japanese government made a decision to construct larger and stronger concrete protection facilities to protect the country's inland areas from such natural hazards. Therefore, tide embankments were built in an extension of 
Table 20.1 List and description of coastal ecosystem services

\begin{tabular}{|c|c|c|}
\hline & Ecosystem services & Coastal-specific components \\
\hline \multirow[t]{3}{*}{$\begin{array}{l}\text { Provisioning } \\
\text { services }\end{array}$} & $\begin{array}{l}\text { Food } \\
\text { provision }\end{array}$ & $\begin{array}{l}\text { a. Fishing activities (including shellfishing) industrial } \\
\text { or artisanal (either commercial or subsistence fishing). } \\
\text { In general, fisheries are reported as total landings or } \\
\text { catch per unit effort and, sometimes, corresponding } \\
\text { jobs } \\
\text { b. Aquaculture is the farming of aquatic organisms, } \\
\text { including fish, crustaceans, mollusks, seaweeds, and } \\
\text { algae }\end{array}$ \\
\hline & $\begin{array}{l}\text { Water storage } \\
\text { and provision }\end{array}$ & $\begin{array}{l}\text { a. Water abstraction in marine and coastal } \\
\text { environments is mostly associated with coastal lakes, } \\
\text { deltaic aquifers, or desalination plants } \\
\text { b. Marine water may also be used for industrial } \\
\text { cooling processes or coastal aquaculture in ponds and } \\
\text { raceways }\end{array}$ \\
\hline & $\begin{array}{l}\text { Biotic } \\
\text { materials and } \\
\text { biofuels }\end{array}$ & $\begin{array}{l}\text { a. This includes medicinal (e.g., drugs, cosmetics), } \\
\text { ornamental (e.g., corals, shells), and other commercial } \\
\text { or industrial resources (e.g., whale oil, fishmeal, seal } \\
\text { leather, algal or plant fertilizers) } \\
\text { b. Biomass to produce energy can have a solid form } \\
\text { (like wood from mangroves), liquid (like fuels } \\
\text { extracted from algal lipids or whale oil), or biogas } \\
\text { (from decomposing material) }\end{array}$ \\
\hline \multirow[t]{4}{*}{$\begin{array}{l}\text { Regulating } \\
\text { and } \\
\text { maintenance } \\
\text { services }\end{array}$} & $\begin{array}{l}\text { Water } \\
\text { purification }\end{array}$ & $\begin{array}{l}\text { Treatment of human wastes (e.g., nitrogen retention); } \\
\text { dilution; sedimentation, trapping, or sequestration } \\
\text { (e.g., of pesticide residues or industrial pollution); } \\
\text { bioremediation (e.g., bioaugmentation after marine oil } \\
\text { spills); oxygenation of "dead zones"; filtration and } \\
\text { absorption; remineralization; and decomposition }\end{array}$ \\
\hline & $\begin{array}{l}\text { Air quality } \\
\text { regulation }\end{array}$ & $\begin{array}{l}\text { Vegetation (e.g., in mangroves), soil (e.g., in } \\
\text { wetlands), and water bodies (e.g., open ocean), due to } \\
\text { their physical structure and microbiological } \\
\text { composition, absorb air pollutants like particulate } \\
\text { matter, ozone, or sulfur dioxide }\end{array}$ \\
\hline & $\begin{array}{l}\text { Coastal } \\
\text { protection }\end{array}$ & $\begin{array}{l}\text { Natural defense of the coastal zone against inundation } \\
\text { and erosion from waves, storms, or sea-level rise. } \\
\text { Biogenic and geologic structures that form the coastal } \\
\text { habitats can disrupt the water movement and, thus, } \\
\text { stabilize sediments or create buffering protective zones }\end{array}$ \\
\hline & $\begin{array}{l}\text { Weather } \\
\text { regulation }\end{array}$ & $\begin{array}{l}\text { For example, the influence of coastal vegetation and } \\
\text { wetlands on air moisture and, eventually, on the } \\
\text { saturation point and the formation of clouds }\end{array}$ \\
\hline
\end{tabular}


Table 20.1 (continued)

\begin{tabular}{l|l|l}
\hline & Ecosystem services & Coastal-specific components \\
\hline maintenance & $\begin{array}{l}\text { The maintenance of key habitats that act as nurseries, } \\
\text { spawning areas, or migratory routes (e.g., seagrasses, } \\
\text { coastal wetlands, coral reefs, mangroves). These } \\
\text { habitats and the connectivity among them are crucial } \\
\text { for the successful life cycle of species. This also } \\
\text { includes pollination (e.g., mangrove pollination) and } \\
\text { seed and gamete dispersal by organisms } \\
\text { This service guarantees the maintenance of genetic } \\
\text { diversity or gene pool protection }\end{array}$ \\
\hline Sultural & $\begin{array}{l}\text { Biological } \\
\text { regulation }\end{array}$ & $\begin{array}{l}\text { Control of fish pathogens especially in aquaculture } \\
\text { installations; role of cleaner fishes in coral reefs; } \\
\text { biological control on the spread of vector-borne human } \\
\text { diseases; and control of potentially invasive species }\end{array}$ \\
\hline $\begin{array}{l}\text { Symbolic and } \\
\text { valuetic }\end{array}$ & $\begin{array}{l}\text { Coastal communities have always shown strong bonds } \\
\text { to the sea due to the local identity. Natural and cultural } \\
\text { sites linked to traditions and religion are numerous in } \\
\text { the coastal zone. Both coastal and inland societies } \\
\text { value the existence and beauty of charismatic habitats } \\
\text { and species such as coral reefs or marine mammals }\end{array}$ \\
\hline $\begin{array}{l}\text { Recreation and } \\
\text { tourism }\end{array}$ & $\begin{array}{l}\text { The appeal of marine ecosystems is usually linked to } \\
\text { wilderness, sports, or iconic landscapes and species. It } \\
\text { can be related to coastal activities (e.g., bathing, } \\
\text { sunbathing, snorkeling, scuba diving) and offshore } \\
\text { activities (e.g., sailing, recreational fishing, whale } \\
\text { watching) }\end{array}$ \\
\hline
\end{tabular}

Modified from Liquete et al. (2013)

approximately $400 \mathrm{~km}$ along the coastlines, thereby replacing the dunes in the process of self-sustaining recovery (Fig. 20.3). The total cost of constructing these tide embankments was over $\$ 10$ billion. Additionally, continuous maintenance costs are also required every year to ensure its integrity and functionality. Although these seawalls ensure a certain level of safety in coastal areas, it has been highlighted that they would prevent the connectivity of ecotones and degrade the resilience of dune ecosystems (Nishihiro et al. 2014).

To make things even worse, black pine trees were replanted in the hinterlands of the seawalls, with an embankment of mountain soil. Coastal forests have been planted in this area for a long time, but most of them were uprooted and/or washed away by the tsunami (Sakamoto 2012; Tanaka et al. 2013). The damage incurred in the trees was a result of the high groundwater levels. This prevented the growth of the plants' root system, thereby restraining the taproot (vertical root) from burrowing deep and developing plate roots (horizontal roots) in thin soil layers (Oda 2001; Hirano et al. 2018). Moreover, the plate root system exhibits lower resistance to uprooting (Dupuy et al. 2005), due to which the black pine trees could not endure the tsunami forces. On account of this, 2-m-high embankments with mountain soils were placed over the sand dunes before replanting new trees to ensure sufficient soil 

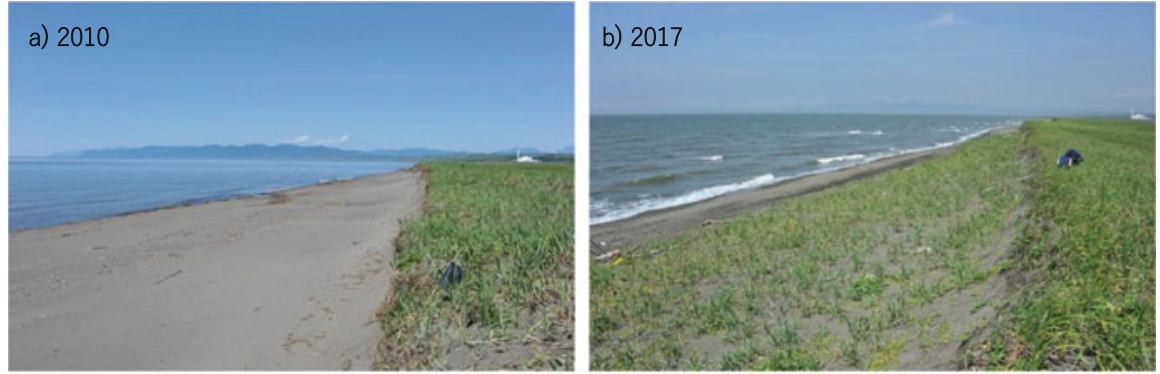

c) Impact of an off-road vehicle driven on coastal dunes and vegetation recovery.
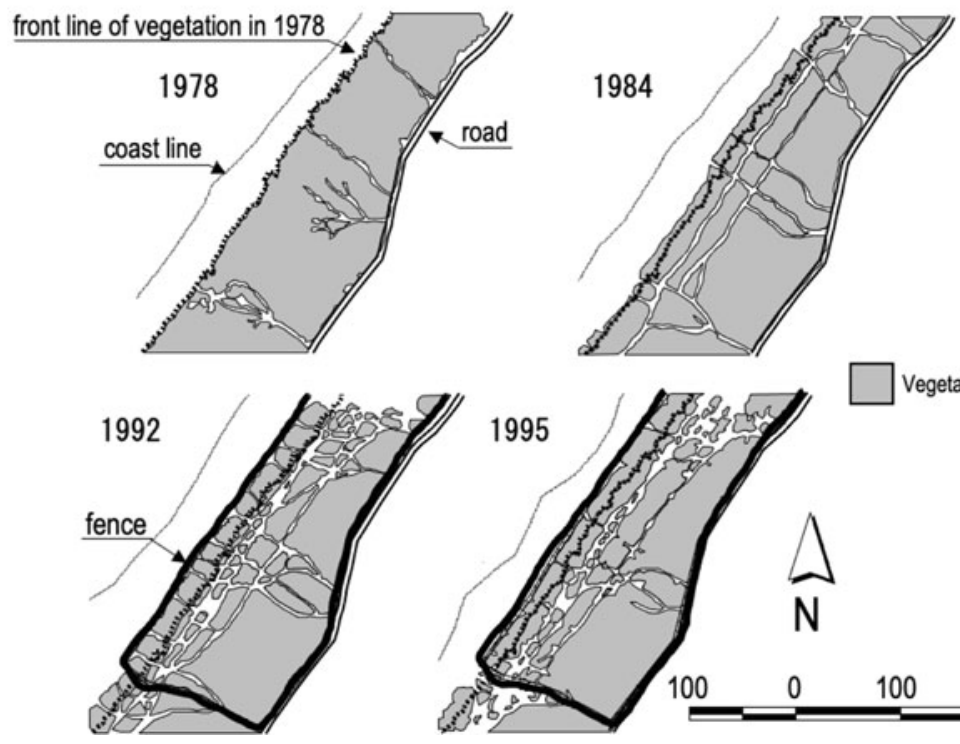

Vegetation coverage

Fig. 20.2 Resilience of coastal dunes on Ishikari coast, Hokkaido, Japan. (a) Foredunes were eroded by winter storm in 2010; (b) dune plants recovered on the beach and regrowth foredunes within several years; (c) impact of an off-road vehicle driven on the coastal dune vegetation. The track of off-road vehicles increased each year until 1992. Once the coastal manager protected these dunes using a fence, dune vegetations recovered $1 \%$ year $^{-1}$ autonomously (Matsushima et al. 2000)

layers for the forest beds. This strategy aimed to encourage the growth of deeper and more vast root systems for holding up a tree and soil particles together.

Adding mountain soil to dune systems causes drastic environmental changes. For example, hardening and densification of mountain soil embankments reduce water permeability and promote the formation of puddles on the surface, which ironically results in a significant inhibition of black pine growth (Ono et al. 2016). Moreover, the seed bank contained in the mountain soil increases the number of inland exotic plants in coastal areas. As a result, natural habitats in coastal ecosystems have been 

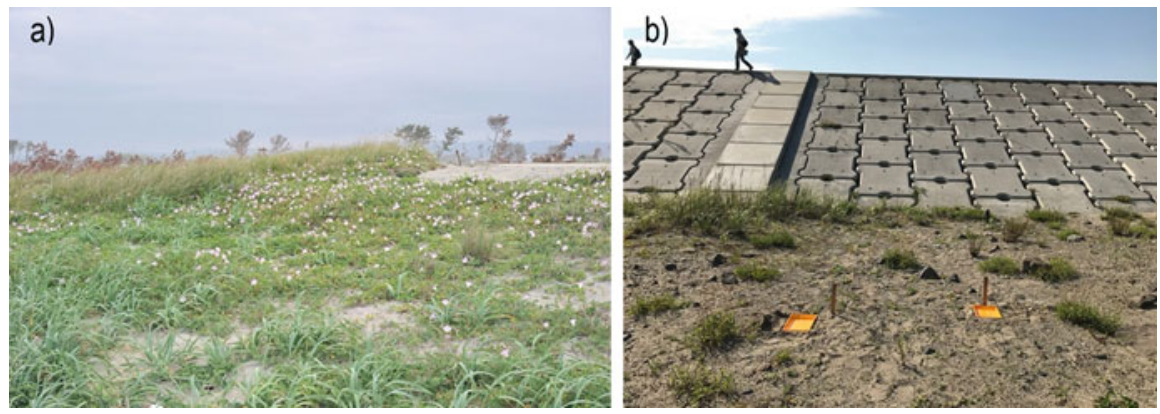

Fig. 20.3 Coastal dunes and seawalls in Yuriage coast, Miyagi, Japan. (a) Autonomously recovered dunes with coastal plants (Calystegia soldanella, Leymus mollis, Carex kobomugi, etc.), June 17, 2011; (b) The dunes were replaced by seawalls at the same place as (a), August 18, 2019
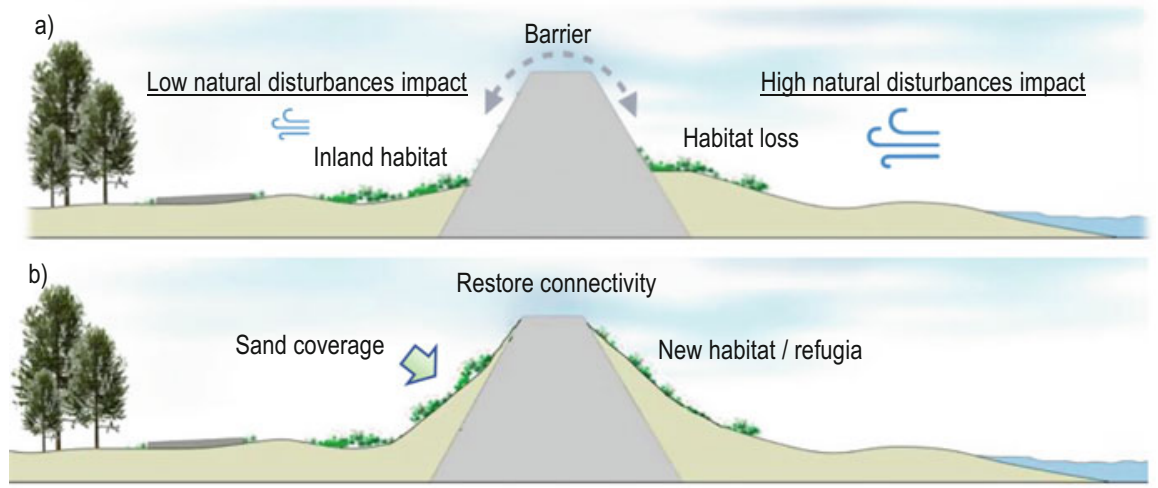

Fig. 20.4 Images of interrupted and connected coastal ecotones. (a) Embankment-interrupted seaside and hinterland environment; (b) sand coverage on the embankment slopes will restore the connectivity and create new habitats and refugia

lost or deteriorated, and their biological communities have suffered changes in the composition of species.

As a result of these recovery and reconstruction processes, the connectivity of coastal ecotones was interrupted by seawalls, and each ecosystem unit was drastically changed by embankment, as shown in Fig. 20.4a.

\subsection{Sand-Covered Embankments as Hybrid Infrastructure for Coastal Community Resilience}

To rehabilitate coastal ecotones and reduce disaster risk and exposure to natural hazards, it is necessary to reduce urban land-use along the coastlines and maintain 
buffer zones in their natural condition (Matsushima and Ferreira 2022). However, it may be difficult to maintain or gain enough space to restore dunes in highly urbanized coastal areas. For instance, residence relocation is not easy, but vacant houses are increasing in urban areas due to a population decline. Moreover, fallow lands are also increasing each year. Therefore, coastal protection and management solutions must be considered thoroughly.

On the other hand, it is relevant to consider what can be done in areas such as the Tohoku region, where seawalls have already been constructed. In Miyagi Prefecture, Japan, a pilot project is being conducted by citizens and a group of researchers, covering the seawalls by sand and turning it into a dune, since 2019 (Matsushima et al. 2019). Conventional studies have shown that coastal plants are required to be moderately disturbed by wind, waves, salt spray, and sand transportation (MorenoCasasola 1986; Oka 2010). Therefore, the effect of wind reduction by seawalls leads to a decrease in natural disturbance from the sea to the hinterland, and as a result, promotes the invasion and settlement of inland (noncoastal) plants and woods. In addition, there was a high risk of habitat shrinkage or loss due to the severe impact of natural disasters at the beach located on the seaside of the seawalls. Therefore, it was considered necessary to restore the connectivity with sand over the tide embankments between the seaside and hinterland ecosystems and to create refugia for biological communities, as shown in Fig. 20.4b.

Traditionally, sand dune systems have been used to protect hinterlands in Japan, as in other countries. In some cases, sand dunes have been artificially formed and used as natural dikes (Perk et al. 2019). In the same line of reasoning, there also exists a conceptual hybrid plan that combines the strength of a seawall with the multiple functions of a sand dune (Almarshed et al. 2020).

The pilot project in Miyagi prefecture began on June 5, 2019, with the cooperation of the Sendai Civil Engineering Office, in Miyagi Prefecture. Using the dredged sand from the Nanakita River estuary sandbar, the sand was covered over an area of $150 \mathrm{~m}$, with a thick layer of $30 \mathrm{~cm}$, on both slopes of the tide embankments (T.P. 7.2 m, Slope gradients 1:2). The Nanakita River constitutes the same sediment transport system as the pilot site. It was also confirmed in advance that the sediment used had the same particle size composition and $\mathrm{pH}$ value as the pilot site beach. To reduce the mixing of mud as much as possible, the surface sand of the estuary sandbar was used as the dredged sand. Since it was collected from a place strongly affected by waves, the EC value showed a considerably high average of ten times, and more compared to the sand around the pilot site. However, 1 year later, it indicated the same value as the surrounding area.

As a result, the vegetation coverage in the sand-covered area increased fivefolds during 2019-2020, as shown in Fig. 20.5. It displayed the efficiency to promote vegetation coverage to cover the seawall with sand. This hybridization of green and gray infrastructure is expected to ensure the connectivity of ecotones and generate new habitats, in addition to the disaster protection function. The seawall will also be protected from time deterioration effects, namely those caused by wave attacks, sand erosion, ultraviolet radiation, corrosion due to sea breeze, and sun heating. In fact, when comparing the surface temperature of the seawall with and without sand 

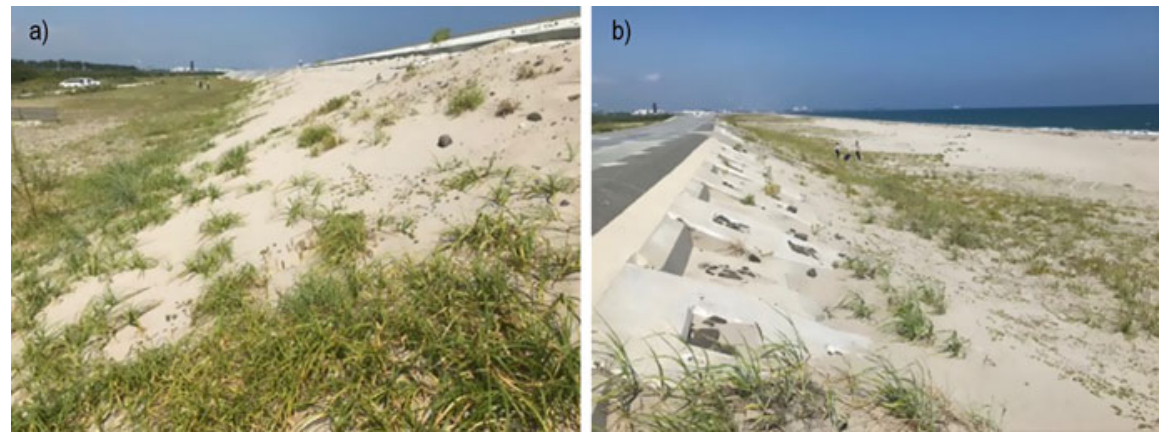

Fig. 20.5 Vegetation coverage area after 1 year (2020). (a) Hinterland side slope; (b) seaside slope

cover, the daily range sometimes became $30{ }^{\circ} \mathrm{C}$ or more without sand cover, but remained within $5{ }^{\circ} \mathrm{C}$ under sand cover. A moisturizing effect was also expected because the plants were settled in. Consequently, the lifespan of this seawall will be extended by hybridization.

This pilot project was conducted with citizen group "Kita-no-satohama Hanano-kakehashi network." This group involved local residents, the elementary school, and junior high school students as a segment of their educational program. It is imperative to connect local residents to the coast. This is because many coastal areas have been designated as disaster risk areas and are being separated from daily life due to them being dangerous places, especially for young children. In this program, students went to the beach to learn coastal environments and collected the seeds of coastal plants to grow seedlings in their schools. Furthermore, the next students came to transplant grown seedlings on these sand-covered embankments to promote "hybrid infrastructure." This project was called "raise the tide embankment" by local residents and students. They learnt more about coastal environments while also inculcating disaster prevention education and learning from local history, culture, and identities. From an infrastructure maintenance aspect, citizens would be an accessible and feasible source of plant maintenance. In addition, because elementary and junior high schools enroll new students every year, it can be stated that this is a developmental project that guarantees sustainability and involvement of a greater number of people each year.

\subsection{Conclusion}

Needless to say, it is important to preserve coastal ecotones and utilize their functions. On the other hand, the scope of hybrid infrastructures such as sand coverage on the tide embankments that complementarily utilize the functions of green and gray infrastructures has also become apparent. Therefore, by covering the 
tide embankments with sand, it is possible to nourish the ecotones while maintaining the required disaster prevention and reduction functions.

In addition, the sand-covered embankments allow the participation of various people. In the case of conventional gray infrastructure, it was difficult for local citizens to participate in its maintenance. However, in the case of these sand-covered embankments, even elementary school students can participate in the regeneration process of the native dune plant community. Currently, it is difficult for children to approach these coastal areas designated as disaster risk areas, but through such maintenance of the sand-covered embankments, it is possible to touch and learn about the natural environment of these areas. Furthermore, they will be able to learn not only about the natural environment but also about the local history and culture that has lived and grown with nature. It will also be used as a place for disaster prevention and reduction education.

Sand-covered embankments, a hybrid infrastructure aimed at restoring ecosystems, could contribute to the establishment of new, resilient coastal communities. This effort has just begun. We would like to collect more data and establish a new infrastructure that is multifunctional, allows various people to participate, and grows over time.

\section{References}

Almarshed B, Figlus J, Miller J, Verhagen HJ (2020) Innovative coastal risk reduction through hybrid design: combining sand cover and structural defenses. J Coastal Res 36(1):174-188

Benedict MA, McMahon ET (2002) Green infrastructure: smart conservation for the 21st century. Renew Resour J 20(3):12-17

Brown S, Nicholls R, Hanson S et al (2014) Shifting perspectives on coastal impacts and adaptation. Nat Clim Chang 4:752-755. https://doi.org/10.1038/nclimate2344

Dupuy L, Fourcaud T, Stokes A (2005) A numerical investigation into the influence of soil type and root architecture on tree anchorage. Plant Soil 278:119-134

Hirano Y, Todo C, Yamase K, Tanikawa T, Dannoura M, Ohashi M et al (2018) Quantification of the contrasting root systems of Pinus thunbergii in soils with different groundwater levels in a coastal forest in Japan. Plant Soil 426:327-337

Kark S (2013) Effects of ecotones on biodiversity. In: Levin SA (ed) Encyclopedia of biodiversity, vol 3, 2nd edn. Academic Press, Waltham, pp 142-148

Kummu M, Moel H, Salvucci G, Viviroli D, Ward PJ, Varis O (2016) Over the hills and further away from coast: global geospatial patterns of human and environment over the 20th-21st centuries. Environ Res Lett 11:034010

Liquete C, Piroddi C, Drakou EG, Gurney L, Katsanevakis S, Charef A et al (2013) Current status and future prospects for the assessment of marine and coastal ecosystem services: a systematic review. PLoS One 8(7):e67737. https://doi.org/10.1371/journal.pone.0067737

Matsushima H, Ferreira SMF (2022) Urbanization of Coastal Areas: loss of coastal dune ecosystems in Japan. In: Gonçalves SC, Ferreira SMF (eds) Sandy beaches as endangered ecosystems: environmental problems and possible assessment and management solutions. CRC Press. (in printing)

Matsushima H, Aikoh T, Kondo T, Asakawa S (2000) A study on the change of beach plants cover area on Ishikari coast. Papers on Environmental Information Science 14:295-300. In Japanese with English summary 
Matsushima H, Suzuki A, Kimura K, Zhong X, Hirabuki Y (2019) Greening on the seawall: challenge to conversion from gray to green infrastructure. In: Proceedings of the JpGU meeting 2019: H-DS10-03

Moreno-Casasola P (1986) Sand movement as a factor in the distribution of plant communities in a coastal dune system. Vegetation 65:67-76

Nakamura F, Ishiyama N, Yamanaka S, Higa M, Akasaka T, Kobayashi Y et al (2019) Adaptation to climate change and conservation of biodiversity using green infrastructure. River Res Applic 36:921-933

Nishihiro J, Hara K, Hirabuki Y (2014) Biodiversity conservation and infrastructure reconstruction after a large-scale disaster: lessons from the coastal regions of southern Sendai Bay. Jpn J Conserv Ecol 19:221-226. (in Japanese with English summary)

NPA (National Police Agency) (2020) Police measures and damage situation of the Tohoku-Pacific Ocean Earthquake in 2011. Press release on June 10th, 2020

Oda T (2001) Study on the reaction of planted tree root systems to water-logging and its application to developing forests in damp lowlands of coastal sand dunes. Spec Bull Chiba Pref For Res Center 3:1-78. (in Japanese with English summary)

Oka K (2010) Coastal environment and biodiversity : a case study of conservation and restoration of coastal sand dune vegetation. J Japan Soc Reveget Technol 35(4):503-507. (in Japanese)

Ono K, Imaya A, Takahashi K, Sakamoto T (2016) Evaluation of the berms built on the Restoration of the Mega-Tsunami-Damaged Coastal Forests-Comparison with the effects of soil-scratching as a soil physical correction method among the various types of machinery. Bull Forestry Forest Prod Res Inst 15:65-78. (in Japanese with English summary)

Onuma A, Tsuge T (2018) Comparing green infrastructure as ecosystem-based disaster risk reduction with gray infrastructure in terms of costs and benefits under uncertainty: a theoretical approach. Int J Disaster Risk Reduct 32:22-28

Perk L, van Rijn L, Koudstaal K, Fordeyn J (2019) A rational method for the design of sand dike/dune systems at sheltered sites; Wadden Sea coast of Texel, The Netherlands. J Mar Sci Eng 7:324

Sakamoto T (2012) Regeneration of coastal forests affected by tsunami. Forestry and Forest Products Research Institute

Tanaka N, Yagisawa J, Yasuda S (2013) Breaking pattern and critical breaking conditions of Japanese pine trees on coastal sand dunes in huge tsunami caused by great East Japan earthquake. Nat Hazards 65:423-442

Udo K, Takeda Y (2017) Projections of future beach loss in Japan due to sea-level rise and uncertainties in projected beach loss. Coast Eng J 59(2):1740006-1-1740006-16. https:// doi.org/10.1142/S057856341740006X

Wootton L, Miller J, Christopher MMS, Peek M, Williams A, Rowe P (2016) Dune manual. Sea Grant Consortium, New Jersey

Open Access This chapter is licensed under the terms of the Creative Commons Attribution 4.0 International License (http://creativecommons.org/licenses/by/4.0/), which permits use, sharing, adaptation, distribution and reproduction in any medium or format, as long as you give appropriate credit to the original author(s) and the source, provide a link to the Creative Commons license and indicate if changes were made.

The images or other third party material in this chapter are included in the chapter's Creative Commons license, unless indicated otherwise in a credit line to the material. If material is not included in the chapter's Creative Commons license and your intended use is not permitted by statutory regulation or exceeds the permitted use, you will need to obtain permission directly from the copyright holder. 